\title{
The personality of Marshal Davout in the Russian Campaign of 1812 on the basis of his memoires and documents of personal nature: an analysis of the electronic resources on the topic
}

\author{
Francesco Rubini* \\ Academy of Engineering, Peoples' Friendship University of Russia, School of Historical Studies, \\ Higher School of Economics, Moscow, Russian Federation
}

\begin{abstract}
Louis Nicolas Davout is still one of the most famous and admired marshals of the First French Empire. His qualities as a great commander and brilliant tactician have been the subject of many historiographical works amongst researchers from all over the world. The aim of this work is to examine the personality of Davout according to electronic documents of personal nature and the historiography about the Russian Campaign of 1812. Specific attention deserve several online documents of Russian works analyzed in the article, which have never been translated from Russian, and whose point of view revealed very interesting information, both concordant and discordant, to cross with that of many European analogues. Historical research requires further translation and analysis of the many and still unknown Russian sources on the topic.
\end{abstract}

\section{Introduction}

"Davout was to Napoleon what Arakchéev was to Alexander-though not a coward like Arakchéev, he was as precise, as cruel, and as unable to express his devotion to his monarch except by cruelty. In the organism of states such men are necessary, as wolves are necessary in the organism of nature. [...] Marshal Davout was one of those men who purposely put themselves in most depressing conditions to have a justification for being gloomy. [...] The chief pleasure and necessity of such men, when they encounter anyone who shows animation, is to flaunt their own dreary, persistent activity" [1].

This extract from Tolstoy's "War and Peace" presents a description of Marshal Davout. "Fearsome marshal", "fanatic of order", or "iron marshal" are only few of the many epithets which have long been assigned to this man, for actually he was seen by his contemporaries as a fierce, gloomy and rigid person.

However, from those who knew him personally, we also received discordant opinions. Some of the clearest examples are the famous words of Napoleon himself, according to which he was "one of the most honest and impeccable warriors in France", or the memories of Stendhal, who remembers him as a «great man not yet appreciated for his dignity» [2].

\footnotetext{
* Corresponding author: francesco.rubini@ mail.ru
} 
Louis Nicolas Davout is still one of the most famous and admired marshals of the First French Empire. His biography is well known amongst the historians of our time, and thanks to the researches undertaken all around the world, today we can be proud of a rich spectrum of historiographical and philological works about him [3,4]. Moreover, the immense potential of electronic resources, from which we can take advantage today in any part of the world, permits us to reach a much more eclectic and heterogeneous range of sources to analyze than before. Many university libraries and archives, especially among the most famous ones, offer well-structured and detailed online consultation services, with millions of openly accessible original documents, representing thus for modern researchers a precious method of research and scientific analysis, able to simplify, or even eliminate, physical distance and time consumption.

\section{Research methods}

Russian historiography deserves particular attention about the personality of Marshal Davout; he is often mentioned in the literature and in the studies of many historians, many of which have never been translated. Nevertheless, in this specific sector his biography has never become the subject of a separate in-depth scientific study, except for several articles and notes by Chinjakov, Zakharov and others [5, 6].

This article aims to refer to the personal documents of Marshal Davout. A large basis of historical sources on the topic has survived until our days: his memoirs, his correspondence with Napoleon and his wife, and various orders [7, 8,9]. Moreover, in this work are also presented some of the memories of French generals and eyewitnesses of the events of that tim [10] analyzed in Russian historiography.

The historical value of these sources is great, as the events, customs and attitudes described come from documents of personal origin. Through them, crossing and comparing their information, we can try to reconstruct facts of the past, and sometimes to decipher the personality of the people who lived in a precise time. Currently, we have the opportunity to use a significant set of source study literature on the methods of working with memoirs and, in general, with documents of personal nature. The methodological basis for this article is provided by the work by A.G. Tartakovsky «1812 and Russian memoirs. Experience of source study», whose author examines the development of the memoirs of this time, and tries to select and reconstruct the complex material about the war of 1812 .

\section{Results}

Studying the personality of Marshal Davout, memoirists and researchers mention him as a brilliant and successful commander, a competent military leader, and a good administrator. At the same time, diametrically opposite impressions are often presented about his personal qualities, and exactly these latter elements represent the nucleus of our work. What kind of person was Louis Nicolas Davout then, according to the content of the pages of his memoirs, of the memoirs of his contemporaries and other documents of personal origin?

Reflecting on the attitude towards military service, Davout once wrote: «The most difficult thing in our profession is the execution of the given orders» [7]. In his opinion, the quality of the execution of the orders is first of all a matter of discipline. Throughout his military career, Davout made every effort to establish iron order in the troops entrusted to him. He always required strict observance of the commands, absolute order and subordination. Studying the correspondence of the marshal, we can repeatedly find proofs that he considered unacceptable any objections from subordinates about his decisions and orders: today this is not surprising, knowing well the strict professional nature of the Grande 
Armée. An interesting example is the content of one of his letters to Napoleon, in which the marshal complained about General J. M. Dessaix as follows: «(Dessaix) was imbued with a very bad spirit; by talking against forced marches, he encourages officers and soldiers to complain and discusses [...] all the orders he receives. I have seriously warned him that if he continues, I will consider it my duty to send him to Your Majesty. This will not be a very significant loss in all respects» [8].

Beside this, the marshal always tried to cope with negative events in the army, like violence against civilians or looting, when they occurred. For instance, General K. Kolachkovsky, a veteran of the war of 1812, noted in his work that Davout «did not allow looting, and his reprisals against them (looters) were very prompt» [10].

This statement about the marshal's complete intolerance to such behavior finds confirmation in many other sources, like a famous speech to the troops, in which Davout rigidly admonished his I corps: «Discipline is worthless! But I shall show you an example of how to strengthen discipline. Yes, gentlemen! I tore off the epaulettes of a colonel who went too far, and the emperor removed him from his post. Thirty cuirassiers in this friendly city, where I have my headquarters, indulged in a robbery during broad daylight. Within one hour they were shot. Gentlemen! I remind you of your duty, of the will of the emperor, of my orders. I swear that I will take measures to punish everyone who does wrong, regardless of personality, even the most excellent» [9]. Davout reported the shooting of three soldiers guilty of robberies to the chief of the general staff, Marshal Berthier. «The verdict was carried out this afternoon. [...] I hope this harsh and useful example will work for the troops». Two days later, «three more soldiers "accused of murder and armed robbery" were shot in front of their unit».

This passage clearly enough describes the attitude of the marshal to such unrest, but we should not forget that in 1812 such phenomena as looting, widespread insubordination and violence against civilians became alarming as a result of the lack of supplies and effective cohesion between the corps during the retreat from Moscow. Each marshal tried to take measures in order to prevent or avoid such consequences, and often their personal character reflected in the orders given to soldiers for this purpose. It is important to remember that all of Napoleon's marshals had their own qualities and peculiarities, thanks to which, in fact, have always been considered great commanders.

Returning to the quote above about Davout and his admonition, it is interesting to analyze another passage from Foord's work in support of this statement: «[...] His (Davout) execution of orders was often merciless. [...] (Davout) monitored isolated incidents of looting or violence meticulously. However, other generals were less strict. [...] Ney was less disciplined than Davout, although he was a human and uniform personality, but neither Davout nor Ney can be blamed after all. Troops, by order of Napoleon, had to be supplied at the expense of the country, and the usual discipline of the French army was so shaken by years of organized banditry that all the rest happened naturally» [11].

\section{Discussions}

Several contemporaries of the French marshal, evaluating his character, claimed that the army did not like him, as he was too rigid, arrogant, and proud. Several critics, especially in Russian historiography, accuse him of senseless cruelty, and their idea of him conflicts with the thesis, according to which he despised looting. The previously mentioned General $\mathrm{K}$. Kolachkovsky, like Foord, often calls him «merciless» [10], and states as follows: «[...] Davout could rob a city without the slightest remorse, with the same ease with which Suchet massacred women and children in Lleida» [11].

L.N. Tolstoy knew about these conflicting ideas too. Beside the opening quote we presented above, the writer, in his description of the interrogation of Pierre Bezukhov in front 
of the French marshal, writes: «Davout for Pierre was not just a French general; for Pierre, Davout was a man known for his cruelty. Looking at Davout's cold face [...] Pierre felt that every second of delay could cost him his life» [1].

However, even if Tolstoy incarnated the Russian spirit of his period, we should not forget that his inestimable masterpiece is very important to us as a philological work, rather than an historical one: besides, several historians and philologists underlined the unfair attitude of the writer to Davout in the extract mentioned above. For example, A.Z. Manfred noted that Tolstoy «[...] was misled by sources unilaterally hostile to the general, but in fact Davout was a straightforward and honest soldier, was one of the most talented commanders of the Napoleonic army» [12].

About this erroneous description of Davout by L.N. Tolstoy discusses also the researcher I.I. Bendersky in his work. In particular, he affirms that the description of the French marshal in the novel is «offensively unpleasant», «hostile», «tense». Davout, according to L.N. Tolstoy, «is the personification of the pragmatic motor of the empire, of its operational essence». All this, as the researcher emphasizes, is a great exaggeration and does not correspond to reality [13].

Among Davout's contemporaries, there were those who, recognizing the harsh behavior and tough character of the marshal, claimed that such qualities were required by the laws of wartime. J. Hadley, one of the first biographers of Davout, concluded that «his actions indicated a cruel and insensitive person», but at the same time emphasized that his «callous and ruthless character $[\ldots]$ originates from education as a military man. [...] all this is a natural result of his firm conviction that all means are good to achieve victory» [2].

Contemporaries and historiographers also pointed to Davout's desire to delve into all the smallest details of soldiers' life, and he always made sure that his men did not lack food and uniforms. According to contemporaries, he often put money out of his own pocket to buy missing shoes, blankets, and medical supplies for the units of his corps. It deserves attention to think about what the soldiers of Davout's corps used to say in this regard: «We were in an army where there was the opportunity to eat» [14].

In his memoirs, Davout wrote that in managing administrative activities, in both wartime and peacetime, everything is important, even the smallest details. That is why he often made inspections, during which he checked how well his officers knew their soldiers, and how much they were informed about the situation in their unit and everyday problems of the troop.

Moreover, the French marshal often visited military schools to ensure that the training of NCOs was going in the right direction, and made certain that officers were trained not only as military commanders, but also as mentors who were supposed to know their subordinates and take care of them [9].

Of course, not all contemporaries assessed these activities of the marshal positively. His unexpected visits, his harsh and sometimes very critical statements, and his effort to control everything was perceived in different ways. Some believed that Davout's mannerism was often clumsy and at times downright offensive to those who came across him, especially in the line of duty. According to some memoirists, Davout was one of the strictest commanders of the French army, very few officers agreed to serve under his command. There were frequent situations when officers, transferred to Davout's I corps, after a short period could not withstand the strict requirements of the marshal, and were forced to write a request of transfer to another corps [6].

Thus, the sources used in this work focus on the various qualities of Davout's personality. We see how his contemporaries assessed the activities and personality of Davout in different ways, but we also see how positively researchers write about him, using a variety of historical sources in their works. Therefore, there is nothing demonic and irrational in the image of Davout. He was a Marshal of France, who could demonstrate outstanding organizational, administrative and managerial skills, diligence and discipline. All works about him, or any 
mention of him in the historiography of all schools, unanimously depict him as a brilliant marshal: perhaps for some he could seem merciless, too harsh, or even bloody, but there is no disagreement about his competence, military talent and leadership qualities.

Being so himself, he required the same from his subordinates. The great historian M.I. Bogdanovich in the 1860s stated: «Constant brilliant successes, responsible of raising him in the general opinion, instilled pride in him; realizing his own dignity, he instilled in his subordinates self-respect and unconditional obedience to his master. However, it should be noted that this man, who terrified all those whose fate depended on him, was not cruel and bloodthirsty at all. The Marshal's contemporaries glorified his sense of justice, administrative talents and the exemplary order he introduced, which curbed the most notorious robbers of the quartermaster's unit. It often happened that he softened the severity of the orders he received» $[15]$.

\section{Conclusion}

Without any doubt, Marshal Louis Nicholas Davout still represents one of the most interesting character of his epoch; a great commander, whose soldiers respected, and sometimes even hated, when he was alive and for whom cried when he died. The study of his personal life, despite the precious contribution of great historians and researchers of our days, still represents a challenge with many details to discover, and requires further interest and attention.

\section{References}

1. L. Tolstoy, War and Peace, VI, https://www.gutenberg.org/files/2600/2600-h/2600h.htm

2. Quote from Zakharov, "Marshal Davout", http://www.adjudant.ru/frmarch/davout1815-00.htm

3. J. Gallagher, The Iron Marshal. London (1976)

4. E. Montegut, Le Mareshal Davout: son caractere et son genie (Paris, 1895)

5. N.A. Trojtskij, Novaja i Novejshaja Istorija, 5 (1993)

6. M.K. Chijakov, Voprosy Istorii, 2, 59 (1999)

7. L. N. Davout, Memoire de m. le marechal Davout, prince d'Eckmuhl au Roi (Paris, 1814)

8. G. Fabry, Campagne de Russie. 1812 (Operations militaires, Paris, 1900)

9. O.W. Roder von Bomsdorf, Mittheilungen, Leipzig (1816)

10. K.I. Kolachkovskij, Voenno-istoricheskij sbornik 3, 34 (1911)

11. E. Foord, Napoleon's Russian Campaign of 1812 (London, 1914)

12. A.Z. Manfred, Napoleon Bonaparte (Moscow, 1973)

13. I.I. Benderskij, Novyj Mir, 11 (2011)

14. N.F. Garnich, 1812 (Moscow, 1952)

15. M. Bogdanovich, Istorija vojny 1813 za nezavisimost' Germanii po dostovernym istochnikam 1, 334 (SPB, 1863) 